\title{
The Great Crash of 2008 and the Reform of Economics
}

\author{
Geoffrey M. Hodgson
}

22 June 2009

The Business School, University of Hertfordshire, De Havilland Campus, Hatfield, Hertfordshire AL10 9AB, UK
www.geoffrey-hodgson.info
g.m.hodgson@herts.ac.uk

Published in the Cambridge Journal of Economics, 2009

Keywords: reform of economics, substance versus technique, financial crisis, John Maynard Keynes, Hyman Minsky, free markets, individualism.

JEL Classifications: A11, A13, A20, B50, D80, G01.

\begin{abstract}
The 2008 economic crash led to remarkable shifts of opinion among world leaders. Does this crisis create favourable conditions for the reform and revitalisation of economics itself - from a subject dominated by mathematical techniques to a discipline more oriented to understanding real-world institutions and actors? And why were warnings of financial collapse not heeded? Recent shortcomings are partly related to the global triumph of market individualist ideology and partly to the exaggerated roles of modelling and quantification. These failures of economics are partly peculiar to the discipline and also a result of other wider institutional and cultural forces.
\end{abstract}




\title{
The Great Crash of 2008 and the Reform of Economics
}

\author{
Geoffrey M. Hodgson
}

\begin{abstract}
The 2008 economic crash led to remarkable shifts of opinion among world leaders. Does this crisis create favourable conditions for the reform and revitalisation of economics itself - from a subject dominated by mathematical techniques to a discipline more oriented to understanding real-world institutions and actors? And why were warnings of financial collapse not heeded? Recent shortcomings are partly related to the global triumph of market individualist ideology and partly to the exaggerated roles of modelling and quantification. These failures of economics are partly peculiar to the discipline and also a result of other wider institutional and cultural forces.
\end{abstract}

The world financial crash of 2008 signalled the most serious global economic crisis since the Great Depression of the 1930s. ${ }^{1}$ Just as John Maynard Keynes is remembered for his critique of the economic theories and policies of his day, critics of mainstream economics may wonder if the latest crisis will help to revive the discipline by exposing the limitations of current economic theory and policy. This article assesses the prospects of such a renewal. It is argued that the possibility of redirecting economics into more constructive and relevant channels is less hopeful than it may appear at first sight, because of major institutional and cultural barriers to the reform of the profession. Among these are obsolete disciplinary boundaries, deep specialisation at the cost of synthetic vision, and a cult of metrication and formalisation.

While economics as a discipline evolves slowly, the ideological mood has changed rapidly. The financial crisis of 2008 led to remarkable retractions among world leaders of previous commitments to lightly-regulated financial markets. The market is no longer seen as the solution to every problem. Contrary to his Republican pedigree, the then US President George $\mathrm{W}$. Bush became the exponent of a huge state bale-out of the banks with a massive extension of state ownership within the financial system.

Alan Greenspan, former chairman of the US Federal Reserve, belatedly declared that he had 'made a mistake in presuming that the self-interest of organizations, specifically banks'

\footnotetext{
1 This article uses material from (Hodgson 2008b) and historical passages from Hodgson (2004). The author is very grateful to David Blanchflower, Robert Boyer, Alain Caillé, Gerry Epstein, Olivier Favereau, Deirdre McCloskey, Richard Nelson, Pascal Petit, anonymous referees and others for helpful comments and discussions.
} 
would protect 'shareholders and equity in the firms'. He had 'discovered a flaw in the model' of liberalisation and self-regulation. ${ }^{2}$

All UK Prime Ministers and Chancellors of the Exchequer since 1979 have promoted market liberalisation. As late as 8 November 2005 the then Labour Chancellor Gordon Brown spoke to the Confederation of British Industry and explained his policy on financial regulation as 'not just a light touch but a limited touch.'3

Yet everything changed with the global financial crisis. Prime Minister Brown adopted a package of measures including partial state ownership of banks. On 19 October 2008 the Chancellor of the Exchequer Alistair Darling announced massive government borrowing to kick-start the British economy. He said that the Keynes's ideas were coming back into vogue. ${ }^{4}$

These changes in ideology among world politicians create a different environment for economists. But as yet there are no strong shifts of opinion or practice among academic leaders of our profession. We search in vain for similar conversions or recantations. The signs are of 'business as usual' (Cohen 2009).

This essay discusses the relationship between the economics profession and the 2008 crash. Section 1 considers some economists who warned of the crisis. Section 2 compares the new affection for Keynes among some politicians and journalists with the declining interest by economists not only in the economics of Keynes but also in other classic economics texts. Sections 3 and 4 consider the priority of technique over substance in modern economics, and whether earlier economic crises provide evidence that this priority is likely to be reversed. Section 5 considers why warnings of the crisis were ignored. Section 6 diagnoses the malady of technique-fixation in economics. Section 7 concludes the essay.

\section{Prophets of doom}

Who were the prophets of the crash of 2008? On 7 September 2006, Nouriel Roubini, an economics professor at New York University, told International Monetary Fund economists that the US was facing a collapse in housing prices, sharply declining consumer confidence and a recession. Homeowners would default on mortgages, the mortgage-backed securities market would unravel and the global financial system would seize up. These developments could destroy hedge funds, investment banks and other major financial institutions. Economist Anirvan Banerji responded that Roubini's predictions did not make use of mathematical models and dismissed his warnings as those of a habitual pessimist. ${ }^{5}$

2 Guardian, 24 October 2008.

3

http://www.cbi.org.uk/ndbs/press.nsf/0363c1f07c6ca12a8025671c00381cc7/ee59d1c32ce4ec12802570c7004115 2c? OpenDocument. Accessed 22 January 2009.

4 This does not imply that government policies strictly follow those of Keynes (Kregel 2009), or indeed should do so (Leijonhufvud 2009).

${ }^{5}$ New York Times, 15 August 2008. In fact, Roubini had performed some modelling using time-series data on consumer debt and housing prices. 
The British sociologist Laurie Taylor asked listeners of his weekly BBC radio programme to find an economist who had predicted the 2008 credit crunch. On 15 October 2008 the radio host announced that the most prescient prophet of the outcome of international financial deregulation since 1980 was the relatively obscure British financial economist Richard S. Dale. In his book on International Banking Deregulation, Dale (1992) had argued that the entry of banks into speculation on securities has precipitated the $1929 \mathrm{crash}$, and that growing involvement of banks in securities activities resulting from incremental deregulation since 1980 might precipitate another financial collapse. Dale's book received a mixed review in the Journal of Finance in 1993 and slipped off the citation rankings.

In early 2008, at a time when many leading economists thought that the bank troubles of 2007 would not lead to a downturn, Professor David Blanchflower came to the conclusion in that the unfolding credit crisis would tip the British economy into a recession. As late as June 2008, Federal Reserve Chairman Ben S. Bernanke was confident that the risk of a US recession had diminished. ${ }^{6}$ But Blanchflower, as a member of the Bank of England Monetary Policy Committee, had been arguing for months that not only was the USA moving into negative growth but the same was in prospect for the UK. His view did not prevail on that Committee until September 2008. On what did he base his prognosis? According to Blanchflower (2009) the key evidence of an impending recession in both the US and UK included 'declines in soft surveys such as consumer confidence, and people's views on the job market.' What led him to his view was not a sophisticated mathematical model but an experienced reading of detailed survey evidence. He remarked: 'The forecasting models were largely useless ... forecasters tend to underpredict recessons.'

Several years after his death in 1996, Hyman Minsky has got some credit. In a series of papers, Minsky $(1982,1985,1992)$ argued that financial capitalism has an inherent tendency to instability and crisis, due to speculation upon growing debt. He gave a number of warnings about the severe consequences of global financial deregulation after 1980. His ideas were never popular with the mainstream. Yet as early as 4 February 2008 the New Yorker noted that references to his financial-instability hypothesis 'have become commonplace on financial Web sites and in the reports of Wall Street analysts. Minsky's hypothesis is well worth revisiting.'

There are other claimants to the title of Prophet of the Crash. Many Post Keynesians and others warned since the 1980s of the dangers of expanding derivatives markets, financial deregulation and excessive debt. But we must be wary of extending the list any longer, at least until the criteria involved are clarified. After all, Marxists have been predicting the collapse of capitalism since 1848 . Those that habitually predict doom are bound to be right one day. But that does not mean that their wisdom is superior.

The outstanding prophets in this context are those that added to our understanding of the institutional mechanisms by which massively expanding debt was financed, and who acknowledged its powerful upward trajectory as well as its hidden and growing risk. Essentially, this is not a matter of predicting the timing of a crash, but improving our understanding the covert structures and forces that pushed the economy over a cliff. It means an appreciation of how the debt-boom unleashed by liberalised financial markets created the preconditions for the collapse.

\footnotetext{
6 http://latimesblogs.latimes.com/money_co/2008/06/tuesday-is-sett.html. Accessed 23 April 2009.
} 


\section{But does anyone read Keynes?}

Let us now turn to economics as practised in universities. Politicians, bloggers, newspapers and magazines may have noticed the relevance of such economists as Keynes and Minsky for today, but have they been cherished or rediscovered in departments of economics in the most prestigious universities?

I tried without success to find the work of Keynes or Minsky on any reading list available on the Web of any macroeconomics or compulsory economic theory course in any of the top universities in the world. Instead, there is ample evidence of student proficiency requirements in mathematics.

By searching post-1950 leading journals, we can ascertain how many times the aforementioned authors were cited in each decade. Table 1 shows the results. Keynes remains the most highly cited of the four authors, but his visibility in leading journals has declined dramatically. Other authors who warned of the dangers of financial deregulation receive a low level of citations. Notably, while much of Roubini's work is discursive, the majority of his articles in top journals of economics contain models.

Data for 2008 and 2009 were not available and have to be extrapolated from earlier years in the same decade. Of course when this data becomes available, these two years may show a revival of citations to Keynes and others, but so far there is no sign of this. And a return to 1950s levels would be remarkable.

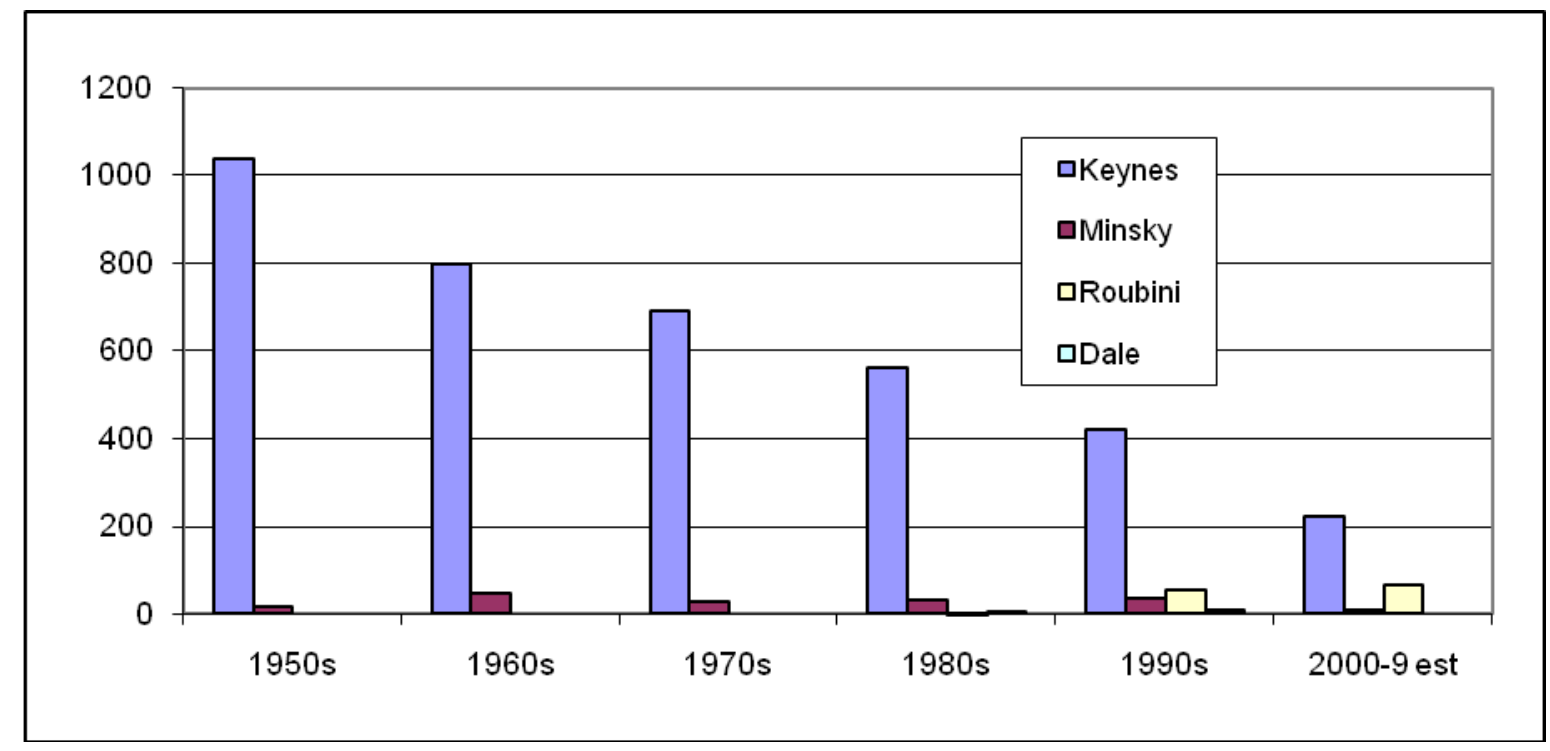

\section{Table 1: Number of Articles or Reviews Citing Keynes, Minsky, Roubini and Dale in Leading Journals of Economics and Finance}

Source: JSTOR. 2008-9 figures are extrapolated from 2000-7 results.

Journals used: American Economic Review, Econometrica, Economic Journal, Economica, Journal of Finance, Journal of Political Economy, Quarterly Journal of Economics, Review of Economic Studies, Review of Economics and Statistics. 
Are academic economists simply citing the wrong people? Such a perception would be mistaken. By citation measures, Keynes's classic antagonists do little better. Take Milton Friedman: from 1950 he was cited by an average of only 344 articles or reviews per decade, in the same list of journals. Friedrich Hayek was cited by only 139 items per decade. Gerard Debreu, a mathematical economist and pioneer of general equilibrium theory, was cited by only 24 items per decade. Mainstream economists seem to have stopped citing anyone, except the most recent pioneers of mathematical technique.

The neglect of the classic texts is dramatically illustrated by the fate of Keynes own ideas. Keynes's wisdom was quickly bowdlerised and forced into a formal model (Robinson 1965, Leijonhufvud 1968, Davidson 1972, Rotheim 1998). Even when Keynes work is acknowledged, it is often in second-hand and suspect terms.

Remarkably, the habit of ignoring past great economists is defended by a professor at the University of Cambridge, in the homeland of Keynes. Partha Dasgupta (2002, p. 61) writes:

You can emerge from your graduate studies in economics without having read any of the classics, or indeed, without having anything other than a vague notion of what the great thinkers of the past had written. The modern economist doesn't even try to legitimize her inquiry by linking it to questions addressed in the canon; she typically begins her article by referring to something in the literature a few months old.

Dasgupta argues that 'on reflection' it is 'not clear' that 'this is an altogether bad state of affairs'. For him, ignoring the past has important positive compensations:

In order to do creative work, there is a further advantage in not being knowledgeable about the intellectual concerns and struggles of bygone eras; there would be a lower risk that the past was setting the present's research agenda.

But our research agenda is always set by the past, even if it may address the future. Our concepts and theories come from the past. It can be no other way. Whether we should be 'knowledgeable about the intellectual concerns and struggles of bygone eras' depends largely on whether these issues are of contemporary relevance or not. Sadly, because we are facing an economic crisis on the scale of the Great Depression, we must learn from that distant experience, as we must learn from other recessions caused by bank failures and from the analyses and policies of dead economists. Yet Dasgupta wishes the past away. Great wisdom is given a short consume-by date, and valuable knowledge is neglected.

Despite this, as Mark Blaug (1991, p. x) points out, few inventors of new ideas in economics can resist the temptation to nominate one or two precursors. Yet as detailed knowledge of the history of economics becomes an unfashionable rarity, the nomination of precursors becomes a shallow ritual. The deeper neglect of past texts undermines habits of careful scrutiny for theoretical precursors, of detailed interrogation of the subtle changes in the meanings of words, of concern for elegant prose and ease of communication, and of attention to careful and precise definition of terms. If anyone bothered to read Keynes then they would find an educated exemplar of these abandoned values - of which we are in dire need today.

\section{The dominance of technique}

To get published in leading journals in economics today it is unnecessary to read or cite any economist beyond the recent past. Most economists are interested in mathematical models. They are taught tools of analysis rather than the intellectual, historical and institutional 
contexts in which analytical questions arise. As mathematics has swamped the curricula in leading universities and graduate schools, student economists have become neither equipped nor encouraged to prioritise real world economies and institutions. Treatment of big questions such as the nature and causes of the wealth and poverty of nations brings no accolade, unless one can reduce the analysis to a respectable formalism.

There have been repeated warnings for over twenty years about this elevation of technique over substance, even in the higher echelons of the profession. The problem became severe by the 1980s. Arjo Klamer and David Colander (1990, p. 18) reported a survey which showed that only 3 per cent of graduate students on top US economics programmes perceived 'having a thorough knowledge of the economy' to be 'very important' for professional success, while 65 per cent thought that 'being smart in the sense of problem-solving' is what matters and 57 per cent believed that 'excellence in mathematics' was very important. Bruno Frey and Reiner Eichenberger (1993, p. 190) likewise remarked that postgraduates are taught 'in a theoryoriented, abstract way and to pay little attention to institutional facts.'

In 1988 the American Economic Association set up a Commission on the state of graduate education in economics in the US. In a crushing indictment, the Commission expressed its fear that 'graduate programs may be turning out a generation with too many idiot savants skilled in technique but innocent of real economic issues' (Krueger et al, 1991, pp. 1044-5). Alan Blinder (1990, p. 445), a member of the Commission, commented:

Both students and faculty find economics obsessed with technique over substance ... the many macro and micro theory exams the Commission examined . . . tested mathematical puzzle-solving ability, not substantive knowledge about economics . . . Only 14 percent of the students report that their core courses put substantial emphasis on 'applying economic theory to real-world problems.'

Since the 1988 Commission there has been a sideline litany of complaints from leading members of the profession. Donald McCloskey (1991, pp. 10-14) wrote:

To put it rigorously, the procedure of modern economics is too much a search through the hyperspace of conceivable assumptions. . . . One economics department after another has been seized by the formalists and marched off to the Gulag of hyperspace searching. Few graduate programs in economics teach economics, especially to first-year students. They teach 'tools,' tools which become obsolete every five years or so.

As Blaug (1997) put it a few years later:

Modern economics is sick. Economics has increasingly become an intellectual game played for its own sake and not for its practical consequences for understanding the economic world. Economists have converted the subject into a sort of social mathematics in which analytical rigour is everything and practical relevance is nothing.

At least three Nobel Laureates have expressed their concerns. At a very early stage Wassily Leontief (1982) objected that models had become more important than data:

Page after page of professional economic journals are filled with mathematical formulas ... Year after year economic theorists continue to produce scores of mathematical models and to explore in great detail their formal properties; and the econometricians fit algebraic functions of all possible shapes to essentially the same sets of data.

Ronald Coase (1997) complained: 'Existing economics is a theoretical system which floats in the air and which bears little relation to what happens in the real world.' And Milton 
Friedman (1999, p. 137) observed: 'economics has become increasingly an arcane branch of mathematics rather than dealing with real economic problems.'

What happened after these prestigious complaints? David Colander (2009) lamented that none of these prominent warnings 'had any effect on US graduate economic education.' As Mark Blaug (1998, p. 45) wrote pessimistically: 'We have created a monster that is very difficult to stop.'

The problem is not necessarily mathematics per se, but the obsession with technique over substance. Arguably there is a proper place for some limited use of useful heuristics or datarich models within economics (Hodgson 2006, ch. 7). But what should determine their adoption is not their technical aesthetics, but their usefulness for helping to explain the real world. ${ }^{7}$

Given the dominance of technique in modern economics, we need to consider how this may have affected the judgement of economists and the advice they gave to policy makers. This question is addressed later. Before doing so we shall examine whether the current economic crisis is likely to undermine or reinforce this formalistic and technical bias, by looking at precedents such as the 1930s.

\section{Did past crises lead economists towards substance rather than technique?}

Mathematical technique was well established in the high temples of economics well before the crash of 2008. By contrast, economics in the 1920s was a much more discursive and less technique-obsessed discipline. Economists received training in the history of their discipline and were aware of longstanding problems and changing theoretical approaches. Hence the tasks of reforming economics today differ substantially from those that faced economists after the Great Crash of 1929.

Keynes' (1936) central theoretical argument was that the assumptions behind laisser faire economics were inappropriate for the real world economic system. ${ }^{8}$ It was not primarily a battle of economic models or econometric techniques. But ironically the Great Depression helped to provide an impetus for more extensive use of mathematics in economics.

A younger generation of economists, impatient with the failure of the older economists to find solutions, turned to mathematical models as well as the Keynesian doctrine. Gunnar Myrdal once reflected on his own experience in the 1930s, when he had played a role in the initiation of the Econometric Society, which was set up to promote formal methods against the then institutionalist hegemony in the USA, and before he himself turned to institutional economics and became a critic of the neoclassical mainstream. Myrdal (1972, pp. 6-7) wrote:

Faced with this great calamity, we economists of the 'theoretical' school, accustomed to reason in terms of simplified macro-models, felt we were on the top of the situation ... It was at this stage that economists in the stream of the Keynesian revolution adjusted their theoretical models to the needs of the time, which gave victory much more broadly to our 'theoretical' approach.

Other commentators reached a similar verdict (Hodgson 2004, pp. 383-6).

\footnotetext{
${ }^{7}$ For useful discussions of the choice, status and explanatory role of models see Sugden (2000) and Mäki (2001, 2005, 2009).

${ }^{8}$ Kregel (2009) argues that Keynes's ideas did not take hold until the late 1930s.
} 
This 'revolution' had established not only a relatively simplified version of Keynesianism but also it was led by a younger generation of economists including Samuelson and others, which promoted formal economic models. They emphasised only those parts of Keynesianism that could be modelled, and were impatient with the apparently equivocal ruminations of older economists that had buried themselves in historical facts in their attempts to understand capitalism's laws of motion.

The attraction of this more mathematical approach was partly its technocratic lure, and partly because it proposed apparent solutions to the urgent problem of the day. It appeared that increasing a variable called $G$ could alleviate the problem of unemployment. The 'solution' was plain and beguiling and dressed up in mathematical and 'scientific' garb. Although Keynes himself warned of the limitations of mathematical technique in economics (Moggridge, 1992, pp. 621-3), he was championed by a younger generation who saw mathematics as the solution.

A second major impetus towards the formalisation of economics was the Second World War. The militarization of scientific activity gave prestige and resources to research involving particular mathematical and statistical techniques. The greatest armed conflict of the twentieth century promoted a central theme of neoclassical economics - the allocation of scarce resources towards the maximization of a fixed objective function with given institutions and assumed technology (Bernstein 2001, Mirowski, 2002).

The emergency of war swept away any reservations concerning sustained government budget deficits. The Great Depression had already persuaded many that some deficit-financed public spending was required (Barber 1988). The war made the conversion total. Anyone who would preach 'balanced budgets' in a sustained wartime emergency could be accused of resisting the war effort. The need for public financing of the war assured the 'Keynesian' victory. Samuelson declared in a 1986 interview: 'By the end of the war the entire academic profession was Keynesian' (Colander and Landreth, 1996, p. 169).

Although the Great Depression established a Keynesian macroeconomics, it also gave impetus to the process of mathematical formalization that gradually accelerated in the postwar period. The pace and extent of this change can be traced in leading journals such as the American Economic Review, the Economic Journal, the Journal of Political Economy and the Quarterly Journal of Economics. Before the 1920s, verbal expositions dominated more than 90 per cent of the articles published in these journals. After 1940, predominantly verbal exposition fell steadily to about 33 per cent of articles in the 1960s. By the early 1990s, over 90 per cent of the articles in the leading and enduring journals were dominated by algebra, calculus and econometrics (Stigler et al, 1995, p. 342)..$^{9}$

Although Keynes fell out of vogue from about 1975 to 2008, and the character of mainstream economics has changed in other respects in recent decades, its obsession with technique over substance remains. The pressing question is whether the crisis of 2008 will reverse this.

We may remind ourselves of an earlier incident. In 1997 Robert C. Merton and Myron S. Scholes were awarded the Nobel Prize in Economics. Scholes had helped to devise the BlackScholes equation, upon which a prominent hedge fund was based. However, following the 1997 financial crisis in Russia and East Asia, the highly leveraged fund lost \$4.6 billion in

\footnotetext{
${ }^{9}$ Blaug $(1999,2003)$ and Weintraub (2002) argue that the 'formalist revolution' in economics was consolidated in the late $1950 \mathrm{~s}$.
} 
less than four months in 1998 and failed. ${ }^{10}$ Did this lead to significant discussion concerning the limits of models? Alas no. ${ }^{11}$

\section{Why were warnings ignored?}

A key issue requiring explanation is not the failure of prediction, because (as noted above) crisis predictions of sorts were made. It is more relevant to ask why well-grounded concerns about the nature and extent of bank lending prior to the crisis were ignored.

In a speech on 21 January 2009, the Chairman of the Financial Services Authority, Lord Adair Turner, pointed to the massive failure 'shared by bankers, regulators, central banks, finance ministers and academics across the world ... to identify that the whole system was fraught with market wide, systemic risk.' ${ }^{12}$ This spreads the blame widely, including to academics, and with some justice. But it fails to explain how such myopia spread simultaneously throughout all these very different political, financial and academic institutions.

The influential economist Richard Posner has addressed the question 'The Financial Crisis: Why Were Warnings Ignored?' on his blog. ${ }^{13}$ He cites Roberta Wohlstetter's famous book Pearl Harbor: Warning and Decision. Wohlstetter (1962) shows that information pointing to the possibility of a Japanese attack on Pearl Harbor was received by the US military, but by different people who were far from each other. It was difficult to collate relevant information, especially among abundant detail and noise. Consequently, individual bits of intelligence were given low credence or priority and did not reach senior military echelons. Posner thus cites Roubini's warnings of economic collapse and argues that these were similarly thwarted within the bureaucracies of the financial and political system:

Among the factors that caused the warnings to be disregarded are factors that may also have been decisive in the neglect of the advance warnings of the financial crisis now upon us: priors (preconceptions), the cost and difficulty of taking effective defensive measures against an uncertain danger, and the absence of a mechanism for aggregating and analyzing warning information from many sources.

This argument has insight on how bureaucracies screen out information but it ignores a fundamental difference. Intelligence of existing preparations for attack is not the same thing as a cognitive appraisal of potential but not yet actual crisis. Furthermore, any reported insight that a financial crisis is possible is likely to be met - at least in contemporary bureaucracies -

\footnotetext{
10 Source http://en.wikipedia.org/wiki/Myron_Scholes (accessed 20 October 2008).

11 There is not the space here to discuss the idea that mathematical models themselves may have changed how financial markets work (MacKenzie 2006). But there is an example of a possible adverse consequence. Mathematical economist David X. Li devised a formula that helped hedge funds assess complex interconnected risks. His formula relies on efficient market valuation and ignores radical uncertainty. In the run-up to the crash it went wildly wrong. See http://www.wired.com/techbiz/it/magazine/17-03/wp_quant?currentPage=all (accessed 20 April 2009).
}

12 Source: http://www.fsa.gov.uk/pages/Library/Communication/Speeches/2009/0121_at.shtml (accessed 22 January 2009).

13 http://www.becker-posner-blog.com/archives/2008/10/the financial_c_2.html. (accessed 18 February 2009). See also Posner (2009). 
by demands for a quantitative assessment of the risk. But with the degree of complexity and openness of the systems involved, a warranted probability assessment is often difficult or impossible. In current bureaucratic cultures, the absence of quantified risk prevented the warnings from being heeded. Also as noted above, Roubini's warnings were disregarded partly because he lacked a sufficiently respectable backup model. These are important differences between the cases of Pearl Harbor and the 2008 Crash. Yet Posner is no straightforward apologist. He singles out economists for special criticism:

Of all the puzzles about the failure to foresee the financial crisis, the biggest is the failure of foresight of professors of finance and of macroeconomics, with a few exceptions such as Roubini. Some of the media commentary has attributed this to economics professors being overly reliant on abstract mathematical models of the economy. In fact professors of finance, who are found mainly in business schools rather than in economics departments, tend to be deeply involved in the real world of financial markets. They are not armchair theoreticians. They are involved in the financial markets as consultants, investors, and sometimes money managers.

This raises a second argument about the role of mathematical models in diverting economists from reality. Posner denies that they have had an adverse effect, and argues that financial economic modellers in business schools were getting their hands dirty in the bustle of money markets. These claims raise still further questions. Why were other professors, in departments of economics, less inclined to be involved in the hurly-burly of market institutions? There is a widespread complaint that we know very little of how market mechanisms actually work (North 1977, p. 710, Coase 1988, p. 7, Härdle and Kirman 1995).

Furthermore, being involved does not mean that one is concerned with the big picture. Most models by financial economists are less concerned with understanding institutional market mechanisms, or even with predicting systemic outcomes, than with providing risk assessment and investment algorithms for client investors. The fallibility of such instrumental models is dramatically illustrated in the Black-Scholes hedge fund scandal. Posner fails to acknowledge that while the financial economists were getting their hands dirty they were ignoring the critical state of the debt-mountain that eventually collapsed.

Warnings were ignored also because an ideology of free markets combined with theoretical claims such as the efficient markets hypothesis and rational expectations. It was widely believed that the market themselves would regulate and control debt. Over-lending would be detected by the market and the stock price of reckless lending institutions would be automatically undermined. Hence government regulation was unnecessary.

The theory of efficient markets claims that prices on traded assets already reflect all known information. This supports light-touch regulation at most. ${ }^{14}$ The rational expectations hypothesis 'asserts that outcomes do not differ systematically ... from what people expected them to be. ... In their efforts to forecast prices, investors comb all sources of information' (Sargent 2008). When economists believe in the informational efficiency of markets and their

14 But this depiction is contestable, partly because costly contract enforcement and irredeemably incomplete markets are neglected. See the empirical evidence and references in Chan et al. (2003) and the powerful critique by Willem Buiter on http://www.voxeu.org/index.php?q=node/3210 (accessed 20 April 2009). 
self-correcting capacity, then warnings of collapse are disregarded because they go against the conventional wisdom. ${ }^{15}$

Also finance professors are attracted to 'the real world of financial markets' partly because of the lucrative consultancy contracts available. Many business schools encourage such consultancy work, and regard it as a mark of relevance and prestige for the school itself. Given the evolution of such vested interests, especially with the global growth of business schools since the 1980s, financial economists had little incentive to call for greater regulation, for restrictions on hedge funds, or raise alarms about the growth of the market for financial derivatives. Vested interests helped to maintain the ideological and policy status quo.

Finally, as noted above, the cult of metrication that prevails in contemporary private and public bureaucracies means that the consultant is pressured to provide a quantitative assessment of any risk. Yet the whole point about complex and open financial markets is that future outcomes are uncertain rather than risky. Uncertainty, at least by the definitions of Knight (1921) and Keynes (1937), applies to circumstances where not quantitative calculation of probability is possible. But few mainstream economists ponder on the difference any more, partly because it is difficult to fit non-quantitative uncertainty into a model. It is a concept banished from mainstream economic theory. ${ }^{16}$ Yet it is very difficult to see how advance predictions of financial catastrophes could have been assessed meaningfully in terms of calculated probabilities. ${ }^{17}$

Consequently, when we consider why warnings of the 2008 crash were not heeded, we are not dealing primarily with a Pearl Harbor syndrome of information uncollated or ignored. Instead, premonitions by experienced analysts were ignored by the mainstream economics profession and financial clients alike because they were neither quantified as probabilities nor derived from respectable models.

\section{Diagnosing sickonomics}

There is now a significant literature on the growth of formalism on economics. Tony Lawson (1997) claims that the use of mathematical models presupposes a 'closed system' ontology that in reality is 'rare'. The details of this argument are controversial (Hodgson 2006, ch. 7) but they do not bear on the main question here: what are the institutional or cultural

\footnotetext{
15 Even now it is easy to find blogs and websites where market individualists blame the collapse not on deregulation, but on too much government intervention in markets, and on incompetent interest rate policy by central banks. Market individualism refers to beliefs in a minimal state, individual private property and competitive free markets. But given that the state is necessary to constitute both money and property rights (Sened 1997, Ingham 2004, Hodgson 2009), we can never in principle reach a utopian market economy where the state plays no role. The diagnostic claims made by market individualists are thus unfalsifiable. Their neglect of large corporations is also a matter of concern (Hodgson 2005). See also Nelson (2005).

16 Lucas (1981, p. 224) wrote: 'In cases of uncertainty, economic reasoning will be of no value'. This is redolent of Arrow's (1951, p. 417) earlier remark that 'no theory can be formulated in this case.' These two authors upheld that 'economic reasoning' and 'theory' were necessarily quantitative, although Arrow later seemed to modify his view.
}

17 A similar failure to give weight to non-quantitative factors such as uncertainty has been seen as biasing decision-making at NASA in the years preceding the 2003 Columbia space shuttle disaster: 'an over-confidence in quantitative data went hand-in-hand with a marginalization of nonquantifiable data, leading to an insensitivity to uncertainty and a loss of organizational memory' (Feldman 2004, p. 691). 
conditions that led to the global rise of formalism in economics? It is important to identify underlying assumptions, but it is another task to explain how they became prominent.

The malady that affects economics has peculiar features, but other disciplines are also afflicted with severe problems. For example, after decades when post-Parsonian sociology has failed to establish a consensus over core assumptions, the reputation of sociological theory has declined and sociology has fractured into a variety of different factional preoccupations, including post-modernism, rational choice theory and naïve empiricism (Mouzelis 1995, Somers 1998).

I suggest that global pressures have impacted on modern universities in the twentieth century and led to significant overall changes in the nature of teaching and research. But the ways in which different disciplines have evolved in response to these pressures reflect varied histories and dynamics. Particularly with formalism in economics, there are strong elements of positive feedback and path dependence. But we also have to understand the general academic context in which these changes take place.

Consider the global change in the nature university education. In developed countries before the Second World War, universities were reserved for a rich or intelligent minority. Despite pressures from business and religious institutions, they managed to dispense a relatively broad education and maintained an ethos for the pursuit of truth. This changed in most developed countries sometime after the Second World War. Especially since the 1960s, the university has become an institution much more oriented to specialist professional training under the behest of business corporations.

Thorstein Veblen (1918) observed some of the early stages of this evolution within universities long ago. Others (Callahan 1962, Bloom 1988, Lutz and Field 1998, Kirp 2003, Greenberg 2007) have charted the post-war decline of broad and questioning inquiry, and the rise of narrower forms of professional training. Students are less encouraged to pursue big questions. They are urged instead to acquire qualifications that signal skills that can be hired on the jobs market.

Behind this process has been the dramatic postwar expansion of systems of higher education in developed capitalist economies, to meet the demands of growing knowledge intensity and relentless specialisation in the sphere of production (Rueschemeyer 1986, Pryor 1996). Deep specialisation means that training in any one area takes more time. Renaissancelike figures with a capacity for an informed overview are less likely to emerge, and even less likely to be acknowledged (Hodgson 1999, pt. 3).

The post-war university expansion had the important benefit of bringing higher learning to a much wider segment of the population. Yet it was impelled by perceived economic needs, and it accelerated the commercialisation of university education. Furthermore, expanded education systems require much more from the public purse, and democratic and other pressures on governments oblige them to account for expenditures in performance terms.

Together these forces eroded enclaves of broad liberal education, vastly expanded specialised professional training, led to explicit requirements to account for the economic value of university research, and promoted the increasing use of league tables and formalised research assessments to pressure academics to publish research in acknowledged outlets.

The cult of quantification has historical sources (Crosby 1998). But it has also received an impetus through the ideology of market individualism since the 1970s. This formalised individual and organisational contractual obligations and enhanced threats of litigation in the case of failure. Organisations have responded in terms of routinised and quantified risk 
assessments. Under equivalent if not greater pressures, similar developments are found in business organisations outside academia. ${ }^{18}$

These background institutional and cultural forces have impacted upon disciplines in different ways. Economics suffered in a peculiar way because it had established a type and degree of formalism that allowed research output to be assessed principally in terms of mathematical interest and elegance. Economists were judged and became employable for their aptitudes for statistical analysis or predictive models.

There is a conservative trend in any science. Robert J. Shiller (2008) writes of the herding of economists around conventional views for fear of bucking the trend. This problem is especially severe in a discipline as monolithic as economics, dominated as it is by relatively few theoretical paradigms and approaches, with the control of journals and other resources concentrated in relatively few academic institutions (Hodgson and Rothman 1999). The oligopolistic distribution of power within the discipline affects both publications and funding. Papers of a less technique-driven nature are more difficult to publish in prestigious journals; grant applications that are bereft of models are unlikely to be approved by refereeing economists; and candidates without a good modelling portfolio are unlikely to be promoted. In a process of cumulative causation, the cult of technique feeds on itself.

Because they are no longer educated to take such issues seriously, mainstream economists care less about the deeper meanings or historical origins of theories or concepts, or about big questions concerning economies and societies.

\section{Conclusion: the reform of economics}

Neither crises nor failures of prediction necessarily impel economists in the direction of realism. One likely reaction to the current downturn is that we should try harder to develop better models. Perhaps we should. But we must also learn the vital lesson that models on their own are never enough. Economists need to appreciate the limitations of modelling. These limitations are generic and result from the intractabilities of uncertainty, complexity and system openness in the real world. A better understanding of our current predicament must also come from a much fuller appreciation of both economic history and the history of ideas. What is required is a revitalisation of the culture within the economics profession.

Colander (2000) and others have argued that much fuller recognition of the reality and implications of the complexity of reality would be helpful for economics. But existing complexity discourse is no panacea. Its diverse content ranges from playful simulation to social constructivism, and it is sometimes of challengeable coherence or value (Horgan 1995). Yet recognition of the limits of modelling in the face of complexity is crucial. Even the most sophisticated of models is inadequate to deal with real-world complexities. Rather than look real-world complexity in the face, economists have retreated into an artificial world of much simpler models. Instead of current practice of valuing many models in terms of their intrinsic technical sophistication, economists should judge models in terms of their ability or otherwise to help us understand and engage with the real world.

\footnotetext{
18 Hunt (2003) argues that because of growing litigational pressure and media scrutiny, large corporations attempt to quantify and minimise risk. See also Froud et al. (2000) for a discussion of related processes of corporate financialisation, involving attempts to maximise shareholder value and the deployment of insured consultants to outsource advice concerning uncertain decisions.
} 
In dealing with uncertain futures, a business technique known as scenario planning is relevant (Loasby 1990, Van der Heijden 1996, Fahey and Randall 1998). Scenario planning addresses plausible future situations and problems. But no attempt is made to assign a probability to each scenario. Scenario planning prepares organisations collectively for dramatic and uncertain events. Prior to 2008, banks and governments could have asked: 'what happens if buyers default on loans and house prices stop rising?' Scenario planners would then consider policies to either avoid or deal with this policy.

But scenario planning creates problems for organisations. Businesses are typically dominated by routine and find it difficult to deal with uncertain futures. Organisations do not handle uncertainty well, and for this reason scenario planning in its radical and original form is not widely adopted. This makes it all the more important for economists to take uncertainty on board, to understand its significance, to urge its importance upon organisations and governments, and help develop strategies to deal with it.

We have also identified the problem of vested interests. Financial economists are less likely to speak out in favour of regulation when they have lucrative consultancy contracts with firms involved with derivatives, hedge funds, and questionable financial innovations. The ideology of market individualism has played havoc with the professional ethics of economists. Mainstream economists declare that everyone is self-interested, so that they cannot be expected to behave ethically in any other sense. The consequence has been a decline in the ethic of professional commitment to truth and some alarming cases of academic plagiarism. The acceptance of a code of ethics for economists may help to reverse this situation and to revive a culture where integrity and professional commitment are valued more highly. ${ }^{19}$

In June 2000 some economics students in leading academic institutions in Paris circulated a petition calling for the reform of their economics curriculum. They complained of a 'disregard for concrete realities' in an approach that 'is supposed to explain everything by means of a purely axiomatic process, as if this were THE economic truth' and called for 'a pluralism of approaches, adapted to the complexity of the objects and to the uncertainty surrounding most of the big questions in economics'. This protest attracted significant global attention and was followed by similar initiatives at the University of Cambridge and elsewhere. ${ }^{20}$

These concerns are as relevant as before. There must be an end to the use of mathematics as 'an end in itself' and to dogmatic teaching styles that leave no place for critical and reflective thought. The teaching of economics must involve an engagement with empirical and concrete economic realities, and a comparative plurality of theoretical approaches.

To understand the current economic crisis we have to look at both economic history and the history of economic thought. To understand how markets work we have to dispense with empty proclamations of rationality and delve into psychology and elsewhere. To understand how economics has taken a wrong turn we have to appreciate work in the philosophy of economics and the relationship between economics and ideology. These unfashionable discourses have to be brought back into the centre of the economic curricula and rehabilitated as vital areas of enquiry. Unless mainstream economics takes heed of these warnings and

19 The Association for Integrity and Responsible Leadership in Economics and Related Professions (AIRLEAP) has been formed to campaign on these issues. See http://www.airleap.org/index.htm.

${ }^{20}$ See http://www.paecon.net/HistoryPAE.htm 
proves its relevance for the understanding of the most severe crisis of the capitalist system since the 1930s, then it will be doomed to irrelevance.

Much greater dialogue is required between economics and the other social sciences. This is not only intrinsically vital, but it has become imperative because both economics and sociology have lost their preceding consensuses concerning the definitions and boundaries of their disciplines (Hodgson 2008a). This suggests a need for some reorganisation of the social sciences in universities.

The changes of heart among politicians and other leaders noted at the beginning of this essay provide an opportunity to appeal beyond the confines for the profession itself. Opinion leaders should be made aware of the malady within our profession and urged to use their influence for reform. If this fails, then broad-minded real-world economics may well have to reorganise itself separately under another label such as 'political economy' or within a broader social science curriculum. 


\section{References}

Arrow, Kenneth J. (1951) 'Alternative Approaches to the Theory of Choice in Risk-Taking Situations’, Econometrica, 19(4), pp. 404-37.

Barber, William J. (1988) From New Era to New Deal: Herbert Hoover, the Economists, and American Economic Policy, 1921-1933 (Cambridge: Cambridge University Press).

Bernstein, Michael A. (2001) A Perilous Progress: Economists and Public Purpose in Twentieth-Century America (Princeton, NJ: Princeton University Press).

Blanchflower, David G. (2009) Email to Geoffrey M. Hodgson of 23 April 2009.

Blaug, Mark (1991) 'Introduction', to Blaug, M. (ed.) (1991) Historiography of Economics (Aldershot: Edward Elgar).

Blaug, Mark (1997) 'Ugly Currents in Modern Economics', Options Politiques, 18(17), September, pp. 3-8. Reprinted in Mäki, Uskali (ed.) (2002) Fact and Fiction in Economics: Models, Realism and Social Construction (Cambridge and New York: Cambridge University Press).

Blaug, Mark (1998) 'The Problems with Formalism: Interview with Mark Blaug', Challenge, 41(3), May-June, pp. 35-45.

Blaug, Mark (1999) 'The Formalist Revolution or What Happened to Orthodox Economics After World War II?', in Backhouse, Roger E. and Creedy, John (eds) (1999) From Classical Economics to the Theory of the Firm: Essays in Honour of D. P. O'Brien (Cheltenham: Edward Elgar), pp. 257-80.

Blaug, Mark (2003) 'The Formalist Revolution of the 1950s', in Samuels, Warren J., Biddle, Jeff E. and Davis, John B. (eds) (2003) A Companion to the History of Economic Thought (Malden, MA and Oxford, UK: Blackwell), pp. 395-410.

Blinder, Alan (1990) 'Discussion', American Economic Review, 80, May, pp. 445-7.

Bloom, Allan (1988) The Closing of the American Mind (New York: Simon and Schuster).

Callahan, R. E. (1962) Education and the Cult of Efficiency (Chicago: University of Chicago Press).

Chan, Kam C., Gup, Benton E. and Pan, Ming-Shiun (2003) 'International Stock Market Efficiency and Integration: A Study of Eighteen Nations', Journal of Business Finance and Accounting, 24(6), March, pp. 803-13

Coase, Ronald H. (1997) 'Interview with Ronald Coase', 17 September 1997, http://www.coase.org/coaseinterview.htm. (Accessed 16 Nov 2008.)

Coase, Ronald H. (1988) The Firm, the Market, and the Law (Chicago: University of Chicago Press).

Cohen, Patricia (2009) 'Ivory Tower Unswayed by Crashing Economy', New York Times, 5 March. http://www.nytimes.com/2009/03/05/books/05deba.html?_r=1\&ref=arts (accessed 20 April 2009).

Colander, David C. (ed.) (2000) The Complexity Vision and the Teaching of Economics (Cheltenham: Edward Elgar).

Colander, David C. (2009) The Making of a European Economist (Cheltenham: Edward Elgar) in press. 
Colander, David C. and Landreth, Harry (eds) (1996) The Coming of Keynesianism to America: Conversations with the Founders of Keynesian Economics (Aldershot: Edward Elgar).

Crosby, Alfred W. (1998), The Measure of Reality: Quantification and Western Society, 1250-1600 (Cambridge: Cambridge University Press).

Dale, Richard S. (1992) International Banking Deregulation: The Great Banking Experiment (Oxford: Blackwell).

Dasgupta, Partha (2002) 'Modern Economics and its Critics', in Mäki, Uskali (ed.) (2002) Fact and Fiction in Economics: Models, Realism and Social Construction (Cambridge: Cambridge University Press), pp. 57-89.

Davidson, Paul (1972) Money and the Real World, 1st. edn. (London: Macmillan).

Fahey, Liam and Randall, Robert M. (eds) (1998) Learning from the Future: Competitive Foresight Scenarios (New York: Wiley).

Feldman, Stephen P. (2004) 'The Culture of Objectivity: Quantification, Uncertainty, and the Evaluation of Risk at NASA', Human Relations, 57(6), pp. 691-718.

Frey, Bruno S. and Eichenberger, Reiner (1993) 'American and European Economics and Economists', Journal of Economic Perspectives, 7(4), Fall, pp. 185-93.

Friedman, Milton (1999) 'Conversation with Milton Friedman', in Brian Snowdon and Howard Vane (eds), Conversations with Leading Economists: Interpreting Modern Macroeconomists (Cheltenham: Edward Elgar), pp. 122-44.

Froud, Julie, Haslam, Colin, Johal, Sukhdev, Williams, Karel (2000) 'Shareholder Value and Financialization: Consultancy Promises, Management Moves', Economy and Society, 29(1), February, pp. 80-110.

Greenberg, Daniel S. (2007) Science for Sale: The Perils, Rewards, and Delusions of Campus Capitalism (Chicago: University of Chicago Press).

Härdle, Wolfgang K. and Kirman, Alan P. (1995) 'Nonclassical Demand: A Model-Free Examination of Price Quantity Relations in the Marseille Fish Market', Journal of Econometrics, 67(1), pp. 227-57.

Hodgson, Geoffrey M. (1999) Economics and Utopia: Why the Learning Economy is not the End of History (London and New York: Routledge).

Hodgson, Geoffrey M. (2004) The Evolution of Institutional Economics: Agency, Structure and Darwinism in American Institutionalism (London and New York: Routledge).

Hodgson, Geoffrey M. (2005) 'Knowledge at Work: Some Neoliberal Anachronisms', Review of Social Economy, 63(4), December, pp. 547-65.

Hodgson, Geoffrey M. (2006) Economics in the Shadows of Darwin and Marx: Essays on Institutional and Evolutionary Themes (Cheltenham: Edward Elgar).

Hodgson, Geoffrey M. (2008a) 'Prospects for Economic Sociology', Philosophy of the Social Sciences, 38(1), March, pp. 133-49.

Hodgson, Geoffrey M. (2008b) 'After 1929 Economics Changed: Will Economists Wake up in 2009?' Real-World Economics Review, no. 48, 6 December, pp. 273-278, http://www.paecon.net/PAEReview/issue48/Hodgson48.pdf 
Hodgson, Geoffrey M. (2009) 'On the Institutional Foundations of Law: The Insufficiency of Custom and Private Ordering’, Journal of Economic Issues, 43(1), March, pp. 143-66.

Hodgson, Geoffrey M. and Rothman, Harry (1999) 'The Editors and Authors of Economics Journals: A Case of Institutional Oligopoly?', Economic Journal, 109(2), February, pp. F165-F186.

Horgan, John (1995) 'From Complexity to Perplexity', Scientific American, June, 272(6), pp. 104-9.

Hunt, Benjamin (2003) The Timid Corporation: Why Business is Terrified of Taking Risk (New York: Wiley).

Ingham, Geoffrey (2004) The Nature of Money (Cambridge: Polity Press).

Keynes, John Maynard (1936) The General Theory of Employment, Interest and Money (London: Macmillan).

Keynes, John Maynard (1937) 'The General Theory of Employment', Quarterly Journal of Economics, 51(1), February, pp. 209-23.

Kregel, Jan A. (2009) 'Why Don't the Bailouts Work? Design of a New Financail System versus a Return to Normalcy', Cambridge Journal of Economics (forthcoming).

Kirp, David L. (2003) Shakespeare, Einstein, and the Bottom Line: The Marketing of Higher Education (Cambridge, MA: Harvard University Press).

Knight, Frank H. (1921) Risk, Uncertainty and Profit (New York: Houghton Mifflin).

Klamer, Arjo and Colander, David (1990) The Making of an Economist (Boulder: Westview Press).

Krueger, Anne O. et al. (1991) 'Report on the Commission on Graduate Education in Economics', Journal of Economic Literature, 29(3), September, pp. 1035-53.

Lawson, Tony (1997) Economics and Reality (London and New York: Routledge).

Leijonhufvud, Axel (1968) On Keynesian Economics and the Economics of Keynes: A Study in Monetary Theory (London: Oxford University Press).

Leijonhufvud, Axel (2009) 'Out of the Corridoor: Keynes and the Crisis', Cambridge Journal of Economics, (published online).

Leontief, Wassily W. (1982) Letter in Science, No. 217, 9 July, pp. 104, 107.

Loasby, Brian J. (1990) 'The Use of Scenarios in Business Planning', in Stephen F. Frowen (ed) (1990) Unknowledge and Choice in Economics (London: Macmillan), pp. 46-63.

Lucas, Robert E., Jr (1981) Studies in Business Cycle Theory (Cambridge, MA and Oxford, UK: MIT Press and Basil Blackwell).

Lutz, Frank W. and Field, Robert W. (1998) Business Valuing in Academia: The American University as a Center for Profit or Inquiry? Higher Education, 36(4), December, pp. 383 419.

MacKenzie, Donald (2006) An Engine, Not a Camera (Cambridge MA: MIT Press).

Mäki, Uskali (2001) 'The Way the World Works (www): Towards an Ontology of Theory Choice', in Mäki, Uskali (ed.) (2001) The Economic World View: Studies in the Ontology of Economics (Cambridge: Cambridge University Press), pp. 369-89. 
Mäki, Uskali (2005) 'Models are Experiments, Experiments are Models', Journal of Economic Methodology, 12(2), June, pp. 303-15.

Mäki, Uskali (2009) 'MISSing the World. Models as Isolations and Credible Surrogate Systems', Erkenn, 70(1), pp. 29-43.

McCloskey, Donald N. (1991) 'Economic Science: A Search Through the Hyperspace of Assumptions?', Methodus, 3(1), June, pp. 6-16.

Minsky, Hyman P. (1982) 'Finance and Profits: The Changing Nature of American Business Cycles', in Hyman P. Minsky, Can 'It' Happen Again?: Essays in Instability and Finance. (Armonk, NY: M.E. Sharpe.)

Minsky, Hyman P. (1985) 'The Financial Instability Hypothesis: A Restatement', in Philip Arestis and Thanos Skouras (eds), Post Keynesian Economic Theory (Armonk, NY: M.E. Sharpe.)

Minsky, Hyman P. (1992) 'The Financial Instability Hypothesis', Jerome Levy Economics Institute Working Paper No. 74. Reprinted in Philip Arestis and Malcom C. Sawyer (eds), Handbook of Radical Political Economy (Aldershot: Edward Elgar).

Mirowski, Philip (2002) Machine Dreams: Economics Becomes a Cyborg Science (Cambridge and New York: Cambridge University Press).

Moggridge, Donald E. (1992) Maynard Keynes: An Economist's Biography (London: Routledge).

Mouzelis, Nicos (1995) Sociological Theory: What Went Wrong? Diagnosis and Remedies (London and New York: Routledge).

Myrdal, Gunnar (1972) Against the Stream: Critical Essays in Economics (New York: Pantheon Books).

Nelson, Richard R. (ed.) (2005) The Limits of Market Organization (New York: Russell Sage Foundation).

North, Douglass C. (1977) 'Markets and Other Allocation Systems in History: The Challenge of Karl Polanyi', Journal of European Economic History, 6(3), Winter, pp. 703-16.

Posner Richard A. (2009) A Failure of Capitalism: The Crisis of '08 and the Descent into Depression (Cambridge MA: Harvard University Press).

Pryor, Frederic L. (1996) Economic Evolution and Structure: The Impact of Complexity on the U.S. Economic System (Cambridge and New York: Cambridge University Press).

Robinson, Joan (1965) Collected Economic Papers - Volume Three (Oxford: Basil Blackwell).

Rotheim, Roy J. (ed.) (1998) New Keynesian Economics/Post Keynesian Alternatives (London and New York: Routledge).

Rueschemeyer, Dietrich (1986) Power and the Division of Labor (Stanford and Cambridge: Stanford University Press and Polity Press).

Sargent, Thomas J. (2008) 'Rational Expectations', The Concise Encyclopedia of Economics, http://www.econlib.org/library/Enc/RationalExpectations.html. Accessed 8 December 2008. 
Sened, Itai (1997) The Political Institution of Private Property (Cambridge: Cambridge University Press).

Shiller, Robert J. (2008) The Subprime Solution: How Today's Global Financial Crisis Happened, and What to Do about It (Princeton NJ: Princeton University Press).

Somers, Margaret R. (1998) 'Symposium on Historical Sociology and Rational Choice Theory "We're No Angels": Realism, Rational Choice, and Relationality in Social Science, American Journal of Sociology, 104(3), November, pp. 722-84.

Stigler, George J., Stigler, Stephen M. and Friedland, Claire (1995) 'The Journals of Economics', Journal of Political Economy, 105(2), pp. 331-59.

Sugden, Robert (2000) 'Credible Worlds: The Status of Theoretical Models in Economics', Journal of Economic Methodology, 7(1), March, pp. 1-31.

Van der Heijden, Kees (1996) Scenarios: The Art of Strategic Conversation (Chichester: Wiley).

Veblen, Thorstein B. (1918) The Higher Learning in America: A Memorandum on the Conduct of Universities by Business Men (New York: Huebsch).

Weintraub, E. Roy (2002) How Economics Became a Mathematical Science (Durham, NC: Duke University Press).

Wohlstetter, Roberta (1962) Pearl Harbor, Warning and Decision (Stanford: Stanford University Press). 